\title{
PENGARUH KEPUASAN DAN KEPERCAYAAN TERHADAP LOYALITAS PELANGGAN RUMAH MAKAN DUA PUTRI DI KELURAHAN MATANO KECAMATAN BUNGKU TENGAH
}

\author{
Muhammad Randi S \\ H. Chalil \\ Ira Nuriya Santi \\ Program Studi S1 Manajemen, Fakultas Ekonomi, Universitas Tadulako \\ Email: muhammadrandis@gmail.com
}

\begin{abstract}
The purpose of this research $\mathbf{\mathbf { \Sigma }} s$ to test and analyze 1) Influence simultaneously variable $\phi$ satisfaction and trust to customer loyality of Two Princess Restaurant in Matano Sub-District of Bungku Tengah District. 2) Partial influence of customer satisfaction variable on customer loyalty Two Putri Restaurant in Matano Village, Central Bungku District. 3) Partial influence of customer trust variable on customer loyalty of Two Princess Restaurant in Matano Sub-district of Bungku Tengah District. This type of research is descriptive causally. Sampling technique using Purposive Sampling, obtained sample of 60 respondents. Data analysis technique is multiple linear regression analysis. The results showed that based on the results of Test $F$, customer satisfaction variables and customer trust simultaneously have a positive and significant impact on customer loyalty Two Putri Restaurant in Matano Village, Central Bungku District. Partially, customer satisfaction variable (XI) has a positive and significant influence on customer loyalty of Two Putri Restaurant in Matano Village, Central Bungku District. The variable of customer trust (X2) has a positive and significant impact on customer loyalty of Two Princess Restaurant in Matano Sub-district, Bungku Tengah District.
\end{abstract}

Keywords: Satisfaction, Trust, Customer Loyalty

\begin{abstract}
Abstrak
Tujuan penelitian adalah untuk menguji dan menganalisis 1) Pengaruh secara simultan variabel kepuasan dan kepercayaan terhadap loyalitas pelanggan Rumah Makan Dua Putri di Kelurahan Matano Kecamatan Bungku Tengah. 2) Pengaruh secara parsial variabel kepuasan pelanggan terhadap loyalitas pelanggan Rumah Makan Dua Putri di Kelurahan Matano Kecamatan Bungku Tengah. 3) Pengaruh secara parsial variabel kepercayaan pelanggan terhadap loyalitas pelanggan Rumah Makan Dua Putri di Kelurahan Matano Kecamatan Bungku Tengah. Tipe penelitian adalah deskriptif kausal. Teknik penarikan sampel menggunakan Purposive Sampling, diperoleh sampel sebanyak 60 responden. Teknik analisis data adalah analisis regresi linier berganda. Hasil penelitian menunjukkan bahwa berdasarkan hasil Uji F, variabel kepuasan pelanggan dan kepercayaan pelanggan secara simultan berpengaruh positif dan signifikan terhadap loyalitas pelanggan Rumah Makan Dua Putri di Kelurahan Matano Kecamatan Bungku Tengah. Secara parsial variabel kepuasan pelanggan $\left(\mathrm{X}_{1}\right)$ berpengaruh positif dan signifikan terhadap loyalitas pelanggan Rumah Makan Dua Putri di Kelurahan Matano Kecamatan Bungku Tengah. Variabel kepercayaan pelanggan $\left(\mathrm{X}_{2}\right)$ berpengaruh positif dan signifikan terhadap loyalitas pelanggan Rumah Makan Dua Putri di Kelurahan Matano Kecamatan Bungku Tengah.
\end{abstract}

Kata Kunci: Kepuasan, Kepercayaan, Loyalitas Pelanggan

\section{PENDAHULUAN}

Fenomena persaingan bisnis khusususnya bisnis Rumah Makan yang ketat dewasa ini khususnya di Kecamatan Bungku Tengah Kabupaten Morowali ditunjukkan dari banyaknya rumah makan yang didirikan. Kondisi ini menyebabkan konsumen dapat membeli menu-menu yang tersedia yang sesuai dengan kebutuhan, keinginan, selera konsumen, dan kemampuan finansial konsumen.Rumah makan Dua Putri berdiri pada tahun 2006 yang berada di wilayah Kabupaten Morowali Kecamatan Bungku 
Tengah. Banyaknya pesaing tidak menghalangi Rumah Makan Dua Putri untuk tetap bertahan, bahkan mampu berkembang sampai sekarang ini.

Fenomena tentang kepuasan pelanggan pada Rumah Makan Dua Putri, bahwa sebagian pelanggan merasa tidak puas dengan pelayanan yang diberikan. Kondisi ini terlihat dari banyaknya pelanggan yang lambat memperoleh pelayanan ketika memesan makanan karena karyawan sangat lambat dalam melayani pelanggan. Selain itu, rasa makanan yang disajikan biasanya kurang memenuhi selera pelanggan dan makanan yang disajikan kurang beragam. Kondisi ini menunjukkan bahwa pihak Rumah Makan Dua Putri masih belum optimal dalam memberikan pelayanan kepada pelanggan sehingga pelanggan menjadi tidak puas ketika melakukan pembelian. Ketidakpuasan pelanggan akan menyebabkan pelanggan menjadi tidak loyal terhadap Rumah Makan Dua Putri sehingga memilih untuk tidak membeli di rumah makan tersebut dan memutuskan untuk berpindah ke rumah makan lainnya.

Kepercayaan pelanggan terhadap Rumah Makan Dua Putri dirasakan pelanggan masih kurang. Fenomena yang terjadi bahwa pihak Rumah Makan Dua Putri di Kelurahan Matano kurang bertanggungjawab dalam memberikan pelayanan kepada pelanggan. Salah satunya adalah ketika pelanggan melakukan pembayaran, pihak rumah makan melebihkan pembayaran dari pelanggan seolah-olah harga yang ditawarkan tidak sesuai dengan harga pada daftar menu. Selain itu, kualitas makanan yang disajikan biasanya makanan yang sudah berapa hari disajkan kembali ke pelanggan. Kondisi ini tentunya menunjukkan bahwa pihak Rumah Makan Dua Putri masih kurang bertanggungjawab kepada pelanggan sehingga pelanggan menjadi tidak percaya ketika melakukan transaksi. Ketidakpercayaan pelanggan akan menyebabkan pelanggan menjadi tidak loyal terhadap rumah makan sehingga memilih untuk tidak membeli produk di rumah makan tersebut dan memutuskan untuk berpindah ke rumah makan lainnya.

Akibat nyata dari permasalahan di atas adalah perkembangan jumlah pelanggan yang tidak terlalu besar atau bahkan pelanggan berhenti dan pindahnya pelanggan ke rumah makan lain akibat kurangnya kepercayaan dan mutu kualitas pelayanan sehingga tidak terjalin kemitraan yang baik antara rumah makan dan pelanggannya. Selain itu, banyaknya rumah makan dan cafe menjadi pilihan konsumen karena menawarkan berbagai macam pilihan produk makanan dan minuman sehingga memungkinkan pelanggan untuk beralih. Kondisi ini akan berdampak terhadap kinerja rumah makan. Dalam hal ini diperlukan suatu usaha yang mengkombinasikan kepercayaan dan kepuasan pelanggan atas kualitas pelayanan untuk meningkatkan loyalitas pelanggan yang dilakukan oleh Rumah Makan Dua Putri di Kelurahan Matano.

Berdasarkan uraian di atas, maka tujuan yang ingin dicapai oleh peneliti dari hasil penelitian ini adalah untuk menguji dan menganalisis kepuasan dan kepercayaan berpengaruh positif dan signifikan terhadap loyalitas pelanggan Rumah Makan Dua Putri di Kelurahan Matano Kecamatan Bungku Tengah.

\section{KAJIAN LITERATUR DAN PENGEMBANGAN HIPOTESIS}

\section{Kepuasan Pelanggan}

Kepuasan pelanggan menurut Kotler (2014:150)adalah perasaan senang atau kecewa yang muncul setelah membandingkan kinerja (hasil) produk yang dipikirkan terhadap kinerja (atau hasil) yang diharapkan. Definisi tersebut mengartikan bahwa apabila kinerja produk tidak sesuai dengan harapan konsumen Rumah Makan dan bila harapan yang ditetapkan terlalu rendah, maka konsumen rumah makan tersebut akan merasa tidak puas dan berujung kecewa, jika kinerja sesuai dengan harapan maka konsumen rumah makan akan merasa puas, namun apabila kinerja produk melampaui harapan, maka konsumen rumah makan akan merasa gembira dan sangat puas. 
Menurut Lovelock dan Wirtz (2011:74) kepuasan adalah suatu sikap yang diputuskan mengenai ciri atau keistimewaan produk atau jasa, atau produk itu sendiri, yang menyediakan tingkat kesenangan konsumen berkaitan dengan pemenuhan kebutuhan konsumsi konsumen. Kepuasan konsumen dapat diciptakan melalui kualitas, pelayanan dan nilai. Kunci untuk menghasikan kesetiaan pelanggan adalah memberikan nilai pelanggan yang tinggi, berdasarkan pengalaman yang didapatkan kepuasan merupakan penilaian.

Menurut Zeithaml (2003:162) terdapat empat faktor yang mempengaruhipersepsi dan ekspektasi pelanggan, yaitu 1) Apa yang telah di dengar pelanggan dari pelanggan lainnya (word of mouth communication). 2) Ekspektasi pelanggan sangat bergantung dari karakteristik individu di mana kebutuhan pribadi (personnel needs). 3) Pengalaman masa lalu (past experience) dalam menggunakan pelayanan dapat juga mempengaruhi tingkat ekspetasi pelanggan. 4) Komunikasi dengan pihak eksternal (external communication) dari pemberi layanan memainkan peranan kunci dalam membentuk ekspektasi pelanggan.

Menurut Irawan (2008:3) kepuasan pelanggan adalah hasil akumulasi dari konsumen atau pelanggan dalam menggunakan produk dan jasa. Pelanggan puas kalau setelah membeli produk dan menggunakan produk tersebut, ternyata kualitas produknya baik. Setiap transaksi atau pengalamam baru, akan memberikan pengaruh terhadap kepuasan pelanggan. Pelanggan yang puas adalah pelanggan yang akan berbagi kepuasan dengan produsen atau penyedia jasa. Pelanggan yang puas akan berbagi rasa dan pengalaman dengan pelanggan lain, sehingga akan menjadi referensi bagi perusahaan yang bersangkutan. Oleh karena itu, baik pelanggan maupun produsen akan sama-sama diuntungkan apabila kepuasan terjadi. Kepuasan akan terjadi kalau perusahaan mampu menyediakan produk, pelayanan, harga dan aspek lain sesuai dengan harapan atau melebihi harapan pelanggan. Pelanggan merasa puas apabila harapannya terpenuhi atau akan sangat puas jika harapan pelanggan terlampaui.

\section{Kepercayaan Pelanggan}

Ferrinadewi (2005:4) mendefinisikan kepercayaan konsumen sebagai persepsi akan keterhandalan dari sudut pandang konsumen yang didasarkan pada pengalaman atau lebih pada urut-urutan transaksi atau interaksi yang dicirikan oleh terpenuhinya harapan akan kinerja produk dan kepuasan. Ishak dan Luthfi (2011:59) mendefinisikan kepercayaan sebagai kesediaan untuk bergantung kepada pihak lain yang telah dipercaya. Berdasarkan dua definisi kepercayaan tersebut dapat disimpulkan bahwa kepercayaan merupakan kesediaan konsumen untuk menggantungkan diri pada suatu produk atau jasa dari suatu perusahaan tertentu yang diyakininya dapat memenuhi kebutuhan mereka.

\section{Loyalitas Konsumen}

Loyalitas didefinisikan suatu sikap yang ditunjukan oleh konsumen terhadap penyediaan produk atau jasa. Seorang konsumen akan menunjukan sikap loyalnya jika perusahaan mampu memberikan kepuasan. Konsumen yang loyal adalah seorang konsumen yang selalu membeli kembali dari provider atau penyedia barang atau jasa yang sama dan memelihara suatu sikap positif terhadap penyedia barang atau jasa itu di masa yang akan datang (Griffin, 2007:7).

Kotler dan Keller (2012:138) loyalitas merupakan komitmen yang dipegang secara mendalam untuk membeli atau mendukung kembali produk atau jasa yang disukai di masa depan meski pengaruh situasi dan usaha pemasaran berpotensi menyebabkan pelanggan beralih.Sedangkan menurut Griffin (2007:24) loyalitas disebutkan sebagai perilaku pembelian yang didefinisikan sebagai pembelian non random yang diungkapkan dari waktu ke waktu oleh beberapa unit.

Menurut Griffin (2007:33), loyalitas dapat didefinisikan berdasarkan perilaku membeli. Adapun karakteristik pelanggan yang loyal antara lain 1) Melakukan pembelian berulang secara teratur. 2) Membeli antarlini produk dan jasa. 3) Mereferensikan kepada orang lain. 4) Menunjukkan kekebalan terhadap tarikan dari pesaing. 


\section{Hubungan Antara Kepuasan Pelanggan dan Loyalitas Pelanggan}

Kepuasan pelanggan merupakan fokus perhatian oleh hampir semua peritel di Indonesia, hal ini disebabkan semakin baiknya pemahaman pelanggan atas konsep kepuasan pelanggan sebagai strategi untuk memenangkan persaingan di dunia bisnis. Kepuasan pelanggan merupakan hal yang penting bagi penyelenggara jasa, karena pelanggan akan menyebarluaskan rasa puasnya kepada calon pelanggan lain, selain itu dengan adanya kepuasan pelanggan dapat meningkatkan loyalitas pelanggan pada suatu perusahaan. Kepuasan dan loyalitas pelanggan pada perusahaan menjadi sangat penting untuk meningkatkan keuntungan sehingga perusahaan selalu menjaga hubungan baik dengan pelanggan.

Menurut Oliver (1997) dalam jangka panjang kepuasan akan berdampak pada terbentuknya loyalitas pelanggan. Ketika pelanggan merasa puas terhadap produk maupun jasa yang diberikan oleh suatu perusahaan maka pelanggan akan cenderung untuk kembali melakukan pembelian ulang terhadap produk maupun mengunjungi jasatersebut dimana hal ini merupakan salah satu indikator dari timbulnya loyalitas pelanggan. Perusahaan harus mampu untuk meningkatkan kepuasan konsumen serta mempertahankan kepuasan konsumen tesebut guna menciptakan loyalitas konsumen terhadap suatu produk. Menurut Kotler dan Keller (2007), kepuasan merupakan hasil evaluasi yang dilakukan konsumen dengan memberikan penilaian terhadap kinerja produk atau merek tertentu dengan harapan yang diinginkannya. Apabila pelayanan sesuai dengan harapan konsumen, maka konsumen akan merasa puas. Adanya kepuasan tersebut, maka konsumen akan membeli ulang produk tersebut secara konsisten sepanjang waktu, sehingga terciptalah loyalitas konsumen terhadap produk atau merek tersebut.

\section{Hubungan Antara Kepercayaan dan Loyalitas Pelanggan}

Kepercayaan diperlukan dalam menjalin hubungan antara perusahaan dan konsumen, dengan keprcayaan dapat menimbulkan loyalitas konsumen terhadap produk atau jasa. Menurut Tjiptono (2008) dalam menjalin hubungan yang baik kepercayaan merupakan faktor penting yang mempengaruhi sebuah komitmen. Apabila tidak ada kepercayaan, maka tidak akan ada komitmen yang tercipta. Adanya komitmen mampu menciptakan konsumen yang loyal karena telah mempercayai kinerja atau kemampuan produk dan perusahaan tertentu.

Morgan dan Hunt (1994) mengungkapkan bahwa perilaku keterhubungan yang terjadi antara perusahaan dan konsumen banyak ditentukan oleh kepercayaan dan komitmen. Jadi, dapat disimpulkan bahwakepercayaan akan mempunyai hubungan yang positif dengan niat ulang maupun loyalitas. Kepercayaan (trust) konsumen mempunyai pengaruh terhadap loyalitas berupa niat ulang melakukan pembelian, dan melakukan intensitas pembelian ulang. Menurut Moorman dkk, (1992), kepercayaan didefinisikan sebagai keinginan dan keyakinan untuk bergantung pada pertukaran mitra. Menurut Rousseau dkk, (1998) mendefinisikan kepercayaan sebagai keadaan psikologis yang terdiri dari maksud untuk menerima kerentanan didasarkan pada perilaku harapan positif dari niat atau perilaku lain.

Hubungan kepercayaan pelanggan mencerminkan semua pengetahuan yang dimiliki oleh konsumen dan semua kesimpulan yang dibuat konsumen tentang objek, atribut, dan manfaatnya. Kepercayaan terhadap objek, atribut, dan manfaat menunjukan persepsi konsumen terhadap suatu retailer dan karena itu umumnya kepercayaan seorang konsumen tentunya berbeda dengan konsumen lainnya terhadap suatu ritel, yakni kepercayaan yang timbul semakin tinggi, maka semakin tinggi pula loyalitas pelanggan.

\section{Hipotesis}

1. Kepuasan dan kepercayaan pelanggan secara simultan berpengaruh positif dan signifikan terhadap loyalitas pelanggan pada Rumah Makan Dua Putri Kelurahan Matano Kecamatan Bungku Tengah. 
2. Kepuasan pelanggan berpengaruh positif dan signifikan terhadap loyalitas pelanggan pada Rumah Makan Dua Putri Kelurahan Matano Kecamatan Bungku Tengah.

3. Kepercayaan pelanggan berpengaruh positif dan signifikan terhadap loyalitas pelanggan pada Rumah Makan Dua Putri Kelurahan Matano Kecamatan Bungku Tengah.

\section{METODE PENELITIAN Jenis Penelitian}

Mengacu pada tujuan penelitian, maka tipe penelitian ini adalah penelitian deskriptif kausal yang dimaksudkan agar dapat melihat secara langsung pengaruh kepuasan dan kepercayaan pelanggan terhadap loyalitas pelanggan Rumah Makan Dua Putri di Kelurahan Matano Kecamatan Bungku Tengah.

\section{Populasi, Sampel dan Teknik Penarikan Sampel}

Populasi adalah wilayah generalisasi yang terdiri atas objek/subjek yang mempunyai kualitas dan karakteristik tertentu yang ditetapkan oleh peneliti untuk dipelajari dan kemudian ditarik kesimpulannya (Sugiyono, 2010). Populasi dalam penelitian ini adalah semua pembeli yang telah melakukan pembelian ulang. Mengingat tidak adanya informasi yang jelas mengenai jumlah pelanggan di Rumah Makan Dua Putri di Keluarahan Matano, maka jumlah populasi dalam penelitian ini tidak diketahui.

Sampel adalah bagian dari jumlah dan karakteristik yang dimiliki oleh populasi tersebut (Sugiyono, 2010). Sampel yang digunakan dalam penelitian ini adalah sebagian dari populasi yang dijadikan responden, yaitu diambil dari sebagian pembeli yang telah melakukan pembelian ulang.Apabila populasi tidak diketahui, menurut Prawira (2010)merekomendasikan jumlah sampel minimal 5 kali dari jumlah item pernyataan yang ada di kuesioner. Total pernyataan dalam penelitian ini adalah 12 pernyataan, sehingga minimal ukuran sampel dalam penelitian ini adalah 12 x $5=60$.

Teknik penarikan sampel yang digunakan dalam penelitian ini yaitu teknik purposive samplingadalah teknik mengambil sampel dengan tidak berdasarkan random, daerah atau strata, melainkan berdasarkan atas adanya pertimbangan yang berfokus pada daerah tertentu (Arikunto, 2006).Adapun kriteria responden yang dijadikan sampel pada penelitian ini adalah 1) Bersedia memberikan tanggapan terhadap kuesioner penelitian.2)Berusia 17 tahun ke atas atau dapat memberikan tanggapan secara objektif. 3) Melakukan pembelian minimal 5 kali pada Rumah Makan Dua Putri.

\section{Metode Pengumpulan Data}

Teknik yang digunakan dalam pengumpulan data penelitian ini adalah 1) Observasi, yaitu peneliti terjun langsung untuk melakukan pengamatan pada para pelanggan Rumah Makan Dua Putri di Kelurahan Matano Kecamatan Bungku Tengah Kabupaten Morowali. 2)Kuesioner, yaitu peneliti membagikan daftar pertanyaan (kuisioner) kepada para responden yang berisi pertanyaan terkait penelitian. Hasil kuesioner ini dianalisis untuk mengetahui sejauh mana pengaruh kepuasan dan kepercayaan pelanggan terhadap loyalitas pelanggan Rumah Makan Dua Putri di Kelurahan Matano Kecamatan Bungku Tengah.3) Wawancara, yaitu peneliti melakukan tanya jawab langsung, kepada pemilik Rumah Makan Dua Putri di Kelurahan MatanoKecamatan Bungku Tengah Kabupaten Morowali mengenai profil usahanya.4) Dokumentasi, yaitu peneliti mengumpulkan data dengan cara mengumpulkan dokumen-dokumenseperti artikel, jurnal, atau hal-hal lainnya yang dianggap berguna untuk penelitian ini. 


\section{Metode Analisis}

\section{Analisis Regresi Berganda}

Alat analisis statistik yang digunakan adalah regresi linear berganda. Menurut Sugiyono (2010) penggunaan analisis regresi linear berganda ini dikarenakan data yang diperoleh dianggap sebagai data populasi dan berdistribusi normal serta antara variabel independen dan dependen terdapat hubungan linear. Untuk meramalkan bagaimana keadaan (naik turunnya) variabel dependen, bila dua atau lebih variabel independen sebagai faktor prediktor dimanipulasi (dinaik turunkan nilainya) dengan formulasi sebagai berikut:

$\mathrm{Y}=\mathrm{a}+\mathrm{b}_{1} \mathrm{X}_{1}+\mathrm{b}_{2} \mathrm{X}_{2} \ldots . \mathrm{b}_{\mathrm{n}} \mathrm{X}_{\mathrm{n}}+€$

\section{Pengujian Hipotesis Pertama (Uji Simultan/Uji F)}

Uji F digunakan untuk menguji tingkat signifikansi variabel-variabel independen secara simultan terhadap variabel dependen. Model dikatakan signifikan jika $F_{\text {hitung }}>F_{\text {tabel }}$ atau nilai sig.F $\leq 0,05$. Variabel independen secara simultan mempunyai pengaruh signifikan terhadap variabel dependen, jika $F_{\text {hitung }}>F_{\text {tabel }}$ atau nilai sig.F $\leq 0,05$.

\section{Pengujian Hipotesis Kedua (Uji Parsial/Uji t)}

Uji t dilakukan untuk menguji signifikansi hubungan antara variabel $(\mathrm{X})$ terhadap variabel $(\mathrm{Y})$ secara terpisah atau parsial. Hipotesis yang digunakan adalah 1) Jika probability (Sig t) $\leq \alpha=0,05$ atau tingkat kepercayaan 95\%, maka seluruh variabel yang terdiri dari harga dan kualitas produk secara parsial berpengaruh signifikan terhadap konsumen yang melakukan pembelian pada Rumah Makan Dua Putri di Kelurahan Matano, dengan kata lain bahwa hipotesis yang diajukan dapat diterima kebenarannya. 2) Jika probability (Sig t) $>\alpha=0,05$ atau tingkat kepercayaan 95\%, maka seluruh variabel yang terdiri dari harga dan kualitas produk secara parsial tidak berpengaruh signifikan terhadap konsumen yang melakukan pembelian pada Rumah Makan Dua Putri di Kelurahan Matano, dengan kata lain bahwa hipotesis yang diajukan tidak dapat diterima kebenarannya.

\section{HASIL DAN PEMBAHASAN}

\section{Hasil Penelitian}

\section{Deskripsi Variabel Penelitian}

\section{Kepuasan Pelanggan $\left(\mathbf{X}_{1}\right)$}

Item pernyataan yang memiliki nilai Mean tertinggi terdapat pada pertanyaan pertama $\left(\mathrm{X}_{1.1}\right)$ dengan nilai Mean 4,20, selanjutnya item pernyataan kedua $\left(\mathrm{X}_{1.1}\right)$ dengan nilai Mean 4,18, kemudian item pernyataan ketiga $\left(\mathrm{X}_{1.3}\right)$ dengan nilai Mean 4,10 , dan item pernyataan keempat $\left(\mathrm{X}_{1.4}\right)$ dengan nilai Mean 4,03.Berdasarkan tanggapan responden pengunjung Rumah Makan Dua Putri di Kelurahan Matano, dominan menanggapi positif pernyataan dari kuesioner variabel kepuasan pelanggan dengan rata-rata nilai Mean 4,13. Interpretasi nilai Mean berada pada nilai 3,41-4,20, memberi makna bahwa tanggapan responden atas variabel kepuasan pelanggan adalah baik.

\section{Kepercayaan Pelanggan $\left(\mathbf{X}_{2}\right)$}

Item pernyataan yang memiliki nilai Mean tertinggi terdapat pada pertanyaan pertama $\left(\mathrm{X}_{2.1}\right)$ dengan nilai Mean 4,32, selanjutnya item pernyataan kedua $\left(X_{2.2}\right)$ dengan nilai Mean 4,12, kemudian item pernyataan ketiga $\left(\mathrm{X}_{2.3}\right)$ dengan nilai Mean 4,10 , dan item pernyataan keempat $\left(\mathrm{X}_{2.4}\right)$ dengan nilai Mean 4,07.Berdasarkan tanggapan responden pengunjung Rumah Makan Dua Putri di Kelurahan Matano, dominan menanggapi positif pernyataan dari kuisioner variabel kepercayaan pelanggan dengan rata-rata nilai Mean 4,15. Interpretasi nilai Mean berada pada nilai 3,41-4,20, memberi makna bahwa tanggapan responden atas variabel kepercayaan pelanggan adalah baik. 


\section{LoyalitasPelanggan (Y)}

Item pernyataan yang memiliki nilai Mean tertinggi terdapat pada pernyataan keempat $\left(\mathrm{Y}_{4}\right)$ dengan nilai Mean 4,13, selanjutnya item pernyataan kedua $\left(\mathrm{Y}_{2}\right)$ dengan nilai mean 4,17, kemudian item pernyataan pertama $\left(\mathrm{Y}_{1}\right)$ dengan nilai Mean 4,13, dan item pertanyaan ketiga $\left(\mathrm{Y}_{3}\right)$ dengan nilai mean 4,07.Berdasarkan tanggapan responden pengunjung Rumah Makan Dua Putri di Kelurahan Matano, dominan menanggapi positif pernyataan dari kuesioner variabel loyalitas pelanggan dengan rata-rata nilai Mean 4,15. Interpretasi nilai Mean berada pada nilai 3,41-4,20, memberi makna bahwa tanggapan responden atas variabel loyalitas pelanggan adalah baik.

\section{Hasil Perhitungan Regresi Linier Berganda}

Pembuktian hipotesis dalam penelitian ini, dilakukan dengan menggunakan alat analisis regresi linier berganda, di mana alat analisis tersebut digunakan untuk mengetahui bagaimana variabel dependen dapat diprediksi melalui dua atau lebih variabel independen sebagai faktor prediksi. Penelitian ini mencoba untuk melihat seberapa besar pengaruh kepuasan dan kepercayaan terhadap loyalitas pelanggan pada Rumah Makan Dua Putri di Kelurahan Matano. Berdasarkan hasil olah data diperoleh hasil analisis regresi linier berganda pada tabel berikut:

Tabel 1. Hasil Perhitungan Regresi Linier Berganda

\begin{tabular}{|l|c|c|c|c|}
\hline \multicolumn{1}{|c|}{ Variable } & Coefficient & Std. Error & t-Statistic & Sig. \\
\hline \multicolumn{1}{|c|}{ Constanta } & 1,274 & 0,716 & 1,779 & 0,081 \\
\hline Kepuasan $\left(\mathrm{X}_{1}\right)$ & 0,179 & 0,066 & 2,717 & 0,009 \\
\hline Kepercayaan $\left(\mathrm{X}_{2}\right)$ & 0,744 & 0,069 & 10,739 & 0,000 \\
\hline $\begin{array}{l}\text { R Square }=0,893 \\
\text { Adjusted R-squared }=0,889 \\
\text { F-statistik } \quad=237,874 \\
\alpha \quad=0,05 \text { (tingkat kepercayaan 95\%) }\end{array}$ \\
\hline
\end{tabular}

$$
\mathrm{Y}=1,274+0,179 \mathrm{X}_{1}+0,744 \mathrm{X}_{2}
$$

a. Nilai konstanta (a) sebesar 1,274 memiliki arti bahwa loyalitas pelanggan Rumah Makan Dua Putri di Kelurahan Matano sebesar 1,274 sebelum variabel kepuasan $\left(\mathrm{X}_{1}\right)$ dan kepercayaan $\left(\mathrm{X}_{2}\right)$ diteliti.

b. Nilai koefisien variabel kepuasan $\left(\mathrm{X}_{1}\right)$ sebesar 0,179 memiliki arti bahwa terdapat hubungan positif antara variabel kepuasan dengan loyalitas pelanggan Rumah Makan Dua Putri di Kelurahan Matano, atau dengan kata lain apabila variabel kepuasan bertambah ke arah positif, maka loyalitas pelanggan Rumah Makan Dua Putri di Kelurahan Matano akan meningkat secara positif. Hal ini disebabkan karena nilai koefisien regresi bernilai positif atau searah.

c. Nilai koefisien variabel kepercayaan $\left(\mathrm{X}_{2}\right)$ sebesar 0,744 memiliki arti bahwa terdapat hubungan positif antara variabel kepercayaan dengan loyalitas pelanggan Rumah Makan Dua Putri di Kelurahan Matano, atau dengan kata lain apabila variabel kepercayaan bertambah ke arah positif, maka loyalitas pelanggan Rumah Makan Dua Putri di Kelurahan Matano akan meningkat secara positif. Hal ini disebabkan karena nilai koefisien regresi bernilai positif atau searah.

\section{Pengujian Hipotesis Pertama (Uji F atau Uji Simultan)}

Hipotesis pertama dalam penelitian ini, menyatakan bahwa kepuasan dan kepercayaan pelanggan secara simultan berpengaruh positif dan signifikan terhadap loyalitas pelanggan Rumah Makan Dua Putri di Kelurahan Matano Kecamatan Bungku Tengah. Nilai F-hituung 237,874 dengan nilai probability (sig.F) $0,000<\alpha=0,05$, maka kepuasan dan kepercayaan pelanggan secara simultan berpengaruh positif dan signifikan terhadap loyalitas pelanggan Rumah Makan Dua Putri Kelurahan Matano, dengan kata lain bahwa hipotesis yang diajukan dapat diterima kebenarannya. 


\section{Pengujian Hipotesis Kedua sampai Ketiga (Uji t atau Uji Parsial)}

Hipotesis kedua sampai ketiga dalam penelitian ini, menyatakan bahwa kepuasan pelanggan berpengaruh positif signifikan terhadap loyalitas pelanggan Rumah Makan Dua Putri di Kelurahan Matano Kecamatan Bungku Tengah. Hipotesis ketiga menyatakan bahwa kepercayaan pelanggan berpengaruh positif signifikan terhadap loyalitas pelanggan Rumah Makan Dua Putri Kelurahan Matano Kecamatan Bungku Tengah.

1) Kepuasan Pelanggan $\left(X_{1}\right)$

Hasil yang diperoleh nilai probability (Sig t) $0,009 \leq \alpha=0,05$ atau tingkat kepercayaan $95 \%$, maka variabel kepuasan pelanggan secara parsial berpengaruh positif dan signifikan terhadap loyalitas pelanggan Rumah Makan Dua Putri di Kelurahan Matano Kecamatan Bungku Tengah, dengan kata lain bahwa hipotesis yang diajukan dapat diterima kebenarannya.

2) Kepercayaan Pelanggan $\left(X_{2}\right)$

Hasil yang diperoleh nilai probability (Sig t) $0,000 \leq \alpha=0,05$ atau tingkat kepercayaan $95 \%$, maka variabel kepercayaan pelanggan secara parsial berpengaruh positif dan signifikan terhadap loyalitas pelanggan Rumah Makan Dua Putri di Kelurahan Matano Kecamatan Bungku Tengah, dengan kata lain bahwa hipotesis yang diajukan dapat diterima kebenarannya.

\section{Pembahasan}

\section{Pengaruh Kepuasan Pelanggan Terhadap Loyalitas Pelanggan Rumah Makan Dua Putri di Kelurahan Matano Kecamatan Bungku Tengah}

Menurut Kotler dan Keller (2007) kepuasan merupakan hasil evaluasi yang dilakukan konsumen dengan memberikan penilaian terhadap kinerja produk atau merek tertentu dengan harapan yang diinginkannya. Bila kinerja sesuai dengan harapan konsumen, maka konsumen akan merasa puas. Adanya kepuasan tersebut, maka konsumen akan membeli ulang produk tersebut secara konsisten sepanjang waktu, sehingga terciptalah loyalitas konsumen terhadap produk atau merek tersebut.

Variabel kepuasan pelanggan $\left(\mathrm{X}_{1}\right)$ yang terdiri dari empat indikator (item pernyataan), yaitu Merasa puas dengan produk yang di sajikan Rumah Makan Dua Putri, selalu membeli produk pada Rumah Makan Dua Putri, Akan merekomendasikan kepada orang lain, Terpenuhinya harapan pelanggan setelah membeli produkberpengaruh signifikan terhadap loyalitas pelanggan pada Rumah Makan Dua Putri di Kelurahan Matano Kecamatan Bungku Tengah. Jadi, artinya bahwa variabel kepuasan pelangganmemiliki pengaruh yang signifikan terhadap loyalitas pelanggan pada Rumah Makan Dua Putri di Kelurahan Matano Kecamatan Bungku Tengah. Sesuai dengan hasil kuisioner di lapangan dengan responden Rumah Makan Dua Putri di Kelurahan Matano yang berjumlah 60 orang, adapun indikator yang terdapat dalam variabel kepuasan pelangganyang mempengaruhi loyalitas pelanggan pada Rumah Makan Dua Putri di Kelurahan Matano dengan empat item pernyataan merasa puas dengan produk yang di sajikan Rumah Makan Dua Putri, selalu membeli produk pada Rumah Makan Dua Putri, akan merekomendasikan kepada orang lain, terpenuhinya harapan pelanggan setelah membeli produk dengan nilai mean 4,13 .

Rumah Makan Dua Putri mengutamakan kepuasan pembeli dengan menyajikan produk yang higienis dan cita rasa masakan yang disukai oleh konsumen. Kualitas produk yang disajikan dapat dilihat dari bahan baku yang digunakan, penyajian yang dilakukan, variasi produk dan atribut yang ada pada produk tersebut seperti rasa, aroma, bentuk, dan penampilan produk.Rumah Makan Dua Putri selalu memberikan kesan yang baik terhadap konsumen sehingga konsumen selalu ingin melakukan pembelian kembali ke Rumah Makan Dua Putri. Adanya kesan baik tersebut, maka konsumen akan merekomendasikan kepada orang lain untuk berkunjung ke Rumah Makan Dua Putri. Ketika seorang konsumen melakukan pembelian, maka banyak harapan-harapan yang diinginkan oleh konsumen mulai dari pertama memasuki rumah makan hingga meninggalkan rumah makan. Rumah Makan Dua Putri selalu peduli dengan pelanggan dan tidak membeda-bedakan setiap pelanggan yang datang 
berkunjung baik dari segi kebutuhannya maupun keinginannya. Kepedulian pihak rumah makan terhadap pelanggan mulai dari proses pelayanan setiap hari dilakukan secara sistematis mulai dari penerimaan pengunjung sampai pengunjung meninggalkan ruangan rumah makan. Setiap konsumen yang datang langsung dilayani dengan baik, hal ini dilakukan untuk memberikan kesan awal yang baik sehingga konsumen merasa nyaman. Mekanisme penyajian menu makanan dilakukan berdasarkan pesanan konsumen saat itu. Konsumen yang berkunjung langsung dilayani dan setiap produk yang dipesan konsumen langsung dicatat dan diproses ke bagian dapur (kitchen area). Variabel kepuasan pelanggan pada Rumah Makan Dua Putri harus tetap dipertahankan, dijaga, dan ditingkatkan, sehingga akan terus ramai dikunjungi pembeli.

Hasil penelitian ini didukung pula oleh penelitian terdahulu yang dilaksanakan oleh Siti dan Aryani (2015) yang menyimpulkan bahwa variabel kepuasan pelanggan berpengaruh positif dan signifikan terhadap loyalitas pelanggan pada Restoran Fast Food Pizza Hut di Jakarta Selatan, artinya apabila kepuasan pelanggan meningkat, maka loyalitas pelanggan akan meningkat.Penelitian yang dilaksanakan oleh Hutomo (2013) yang menyimpulkan bahwa variabel kepuasan konsumen berpengaruh positif terhadap loyalitas pelanggan pada Produk Makanan Tela Krezz Cabang Bekasi, artinya apabila kepuasan pelanggan meningkat, maka loyalitas pelanggan akan meningkat.Hasil penelitian ini sesuai dengan pendapat Oliver (1997) bahwa dalam jangka panjang kepuasan akan berdampak pada terbentuknya loyalitas pelanggan. Ketika pelanggan merasa puas terhadap produk maupun jasa yang diberikan oleh suatu perusahaan maka pelanggan akan cenderung untuk kembali melakukan pembelian ulang terhadap produk maupun mengunjungi jasatersebut dimana hal ini merupakan salah satu indikator dari timbulnya loyalitas pelanggan. Perusahaan harus mampu untuk meningkatkan kepuasan konsumen serta mempertahankan kepuasan konsumen tesebut guna menciptakan loyalitas konsumen terhadap suatu produk.

\section{PengaruhKepercayaan Pelanggan Terhadap Loyalitas Pelanggan Rumah Makan Dua Putri di Kelurahan Matano Kecamatan Bungku Tengah}

Menurut Morgan dan Hunt (1994) mengungkapkan bahwa perilaku keterhubungan yang terjadi antara perusahaan dan konsumen banyak ditentukan oleh kepercayaan dan komitmen. Jadi dapat disimpulkan bahwa kepercayaan akan mempunyai hubungan yang positif dengan niat ulang maupun loyalitas. Kepercayaan (trust) konsumen mempunyai pengaruh terhadap loyalitas berupa niat ulang melakukan pembelian, dan melakukan intensitas pembelian ulang. Hubungan kepercayaan pelanggan mencerminkan semua pengetahuan yang dimiliki oleh konsumen dan semua kesimpulan yang dibuat konsumen tentang objek, atribut, dan manfaatnya. Kepercayaan terhadap objek, atribut, dan manfaat menunjukan persepsi konsumen terhadap suatu retailer dan karena itu umumnya kepercayaan seorang konsumen tentunya berbeda dengan konsumen lainnya terhadap suatu ritel, di mana kepercayaan yang timbul semakin tinggi, maka semakin tinggi pula loyalitas pelanggan.

Variabel kepercayaan pelanggan $\left(\mathrm{X}_{2}\right)$ yang terdiri dari empat indikator (item pernyataan), yaitu mengembalikan barang-barang yangtertinggal, kejujuran penjual dalam bertransaksi, tanggungjawab penjual kepada pembeli, Kepercayaan bahwa perusahaan memiliki reputasi yang baikberpengaruh signifikan terhadap loyalitas pelanggan pada Rumah Makan Dua Putri di Kelurahan Matano Kecamatan Bungku Tengah. Jadi, artinya bahwa variabel kepercayaan pelanggan memiliki pengaruh yang signifikan terhadap loyalitas pelanggan pada Rumah Makan Dua Putri di Kelurahan Matano Kecamatan Bungku Tengah.Sesuai dengan hasil kuisioner di lapangan dengan responden Rumah Makan Dua Putri di Kelurahan Matano yang berjumlah 60 orang, adapun indikator yang terdapat dalam variabel kepercayaan pelanggan yang sangat mempengaruhi loyalitas pelanggan pada Rumah Makan Dua Putri di Kelurahan Matano, yaitu mengembalikanbarang-barang yangtertinggal, kejujuran penjual dalam bertransaksi, tanggungjawab penjual kepada pembeli, kepercayaan bahwa perusahaan memiliki reputasi yang baikdengan nilai mean 4,15. Rumah Makan Dua Putri selalu 
Randi S. M.

mengembalikanbarang-barang yangtertinggal milik pelanggan dengan cara melihat kartu tanda pengenal atau dengan menyimpan barang tersebut sampai pemilik barang tersebut kembali menanyakan barang miliknya atau kembali berkunjung ke Rumah Makan Dua Putri. Pihak Rumah Makan Dua Putri selalu memegang teguh kejujuran dalam bertransaksi yaitu menghitung setiap jumlah makanan dan minuman yang di pesan sesuai dengan harganya tanpa melebih-lebihkan harga dari pesanan tersebut. Pihak Rumah Makan Dua Putri juga sangat bertanggungjawab kepada pembeli yang berkunjung yaitu dengan memberikan pelayanan yang cepat dan terbaik kepada pelanggan sesuai dengan keinginannya sehingga pengunjung merasa puas dan terkesan. Rumah Makan Dua Putri memiliki sangat dipercaya karena memiliki reputasi kinerja yang baik. Rumah Makan Dua Putri sangat di andalkan karena setiap pelanggan yang melakukan pemesanan makanan selalu direspon dengan cepat sesuai dengan keinginan makanan baik dari porsi makanan, kebersihan makanan, cita rasa makanan, kualitas makanan, maupun kecepatan dalam memberikan pelayanan. Apabila kepercayaan, kejujuran, tanggungjawab dalam bentuk pelayanan terus diperhatikan dan dipertahankan, maka dari segi pemasaran akan meningkatkan jumlah kunjungan masyarakat pada Rumah Makan Dua Putri, sedangkan dari segi ekonomi akan memberikan pengaruh positif pada peningkatan volume penjualan, pendapatan, perolehan laba dari pengelolaan usaha Rumah Makan Dua Putri ditengah kompetitifnya persaingan usaha.

Hasil penelitian ini didukung pula oleh penelitian terdahulu yang dilaksanakan oleh Khakim, et al. (2014)yang menyimpulkan bahwa variabel kepercayaan pelanggan berpengaruh positif dan signifikan terhadap loyalitas pada Pizza Hut Cabang Simpang Lima, artinya apabila kepercayaan pelanggan meningkat, maka loyalitas pelanggan akan meningkat.Penelitian yang dilaksanakan oleh Danny dan Chandra (2011) yang menyimpulkan bahwa variabel kepercayaan memiliki hubungan terhadap loyalitas konsumen pada Ayam Penyet Sebagai Menu Unggulan Warung Bu Kris, artinya apabila kepercayaan pelanggan meningkat, maka loyalitas pelanggan akan meningkat. Hasil penelitian ini sesuai dengan pendapat Tjiptono (2008) bahwa kepercayaan diperlukan dalam menjalin hubungan antara perusahaan dan konsumen, dengan keprcayaan dapat menimbulkan loyalitas konsumen terhadap produk atau jasa. Kepercayaan dalam menjalin hubungan yang baik merupakan factor penting yang mempengaruhi sebuah komitmen. Apabila tidak ada kepercayaan, maka tidak akan ada komitmen yang tercipta. Adanya komitmen mampu menciptakan konsumen yang loyal karena telah mempercayai kinerja atau kemampuan produk dan perusahaan tertentu.

\section{KESIMPULAN DAN SARAN}

\section{Kesimpulan}

1. Variabel kepuasan pelanggan dan kepercayaan pelanggan secara simultan berpengaruh positif dan signifikan terhadap loyalitas pelanggan Rumah Makan Dua Putri di Kelurahan Matano Kecamatan Bungku Tengah.

2. Variabel kepuasan pelanggan $\left(\mathrm{X}_{1}\right)$ berpengaruh positif dan signifikan terhadap loyalitas pelanggan Rumah Makan Dua Putri di Kelurahan Matano Kecamatan Bungku Tengah.

3. Variabel kepercayaan pelanggan $\left(\mathrm{X}_{2}\right)$ berpengaruh positif dan signifikan terhadap loyalitas pelanggan Rumah Makan Dua Putri di Kelurahan Matano Kecamatan Bungku Tengah.

\section{Saran}

1. Kepercayaan pelanggan merupakan variabel yang memiliki nilai mean dan koefisien tertinggi dan merupakan variabel dominan yang menjadi pertimbangan pelanggan terhadap loyalitas pelanggan pada Rumah Makan Dua Putri di Kelurahan Matano. Disarankan kepada pihak Rumah Makan Dua Putri di Kelurahan Matano untuk lebih menerapkan strategi, yaitu menanamkan pelayanan yang lebih baik lagi dari pesaing, dengan meningkatkan tanggungjawab, kejujuran, dan kepercayaan 
sehingga dapat memberikan reputasi yang baik dari konsumen dan tidak ada lagi keluhan konsumen mengenai kepercayaan dari pihak rumah makan.

2. Kepuasan pelanggan merupakan variabel yang memiliki nilai mean dan koefisien terkecil terhadap loyalitas pelanggan pada Rumah Makan Dua Putri di Kelurahan Matano. Untuk itulah pihak rumah makan diharapkan dapat mempertahankan kepuasan pelanggannya seperti penyajian makanan, harapan pelanggan, untuk dapat lebih menarik minat pelanggan agar mau membeli lagidan merekomendasikan ke orang lain tanpa menurunkan kualitas produknya. Karena pelanggan pada dasarnya mengharapkan produk makanan yang sesuai bahkan lebih atas harga yang telah dibayarkannya.

3. Kepada peneliti selanjutnya disarankan untuk memasukkan variabel lain, yang dapat mempengaruhi loyalitas pelanggan selain yang digunakan dalam penelitian ini sehingga lebih dapat mengukur sebab-sebab yang mempengaruhi loyalitas pelanggan pada Rumah Makan Dua Putri di Kelurahan Matano Kecamatan Bungku Tengah, selain itu juga sampel yang digunakan lebih luas.

\section{REFERENSI}

Arikunto, Suharsimi, 2006. Prosedur Penelitian Suatu Pendekatan Praktik, Edisi Revisi.Jakarta: PT. Rineka Cipta.

Danny dan Chandra, 2011. Analisis Kepuasan dan Loyalitas Konsumen Terhadap Tingkat Penjualan di Warung Bu Kris (Studi Kasus Pada Ayam Penyet Sebagai Menu Unggulan Warung Bu Kris). Jurnal Manajemen dan Kewirausahaan, Vol. 3, No. 2, ISSN 2338-8234

Ferrinadewi, E., 2005. Pengaruh Tipe Keterlibatan Konsumen TerhadapKepercayaan Merek dan Dampaknya Pada Keputusan Pembelian.Jurnal Modus,Vol. 17, No. 1.

Griffin, Ricky W, 2007. Bisnis. Edisi Kedelapan. Jilid I. Jakarta: Erlangga.

Hutomo, Agyl Satrio, 2013. Pengaruh Kualitas Produk dan Tingkat Kepuasan Konsumen Terhadap Loyalitas Pelanggan Pada Produk Makanan Tela Krezz Cabang Bekasi. Artikel Fakulatas Ekonomi, Universitas Gunadarma.

Irawan, Handi, 2008. Membedah Strategi Kepuasan Pelanggan. Cetakan Pertama. Jakarta: PT. Gramedia.

Ishak,Adan Luthfi Z., 2011. Pengaruh Kepuasan dan Kepercayaan Konsumen Terhadap Loyalitas: Studi Tentang Peran Mediasi Switching Costs, Jurnal Siasat Bisnis, Vol. 15, No.1, Hal 45 - 56.

Khakim, Lukman, Fathoni, Azis, dan Minarsih, Maria, M, 2014. Pengaruh Kualitas Pelayanan, Harga dan Kepercayaan Terhadap Loyalitas Pelanggan dengan Variabel Kepuasan Pelanggan Sebagai Variabel Intervening Pada Pizza Hut Cabang Simpang Lima. Artikel Fakultas Ekonomi Universitas Pandanaran Semarang.

Kotler, Philip, 2014. Prinsip-Prinsip Pemasaran, Edisi Ketiga. Jilid 1. Terjemahan Bob Sabran. Jakarta: Erlangga.

Kotler, Philip dan Keller, Kevin, Lane, 2007. Manajemen Pemasaran,Edisi 12, Jilid 1. Jakarta: PT.Indeks.

Kotler, Philip dan Keller, Kevin, Lane, 2012, Manajemen Pemasaran. Edisi 14, Jilid 2. Jakarta: PT.Indeks.

Lovelock, Christopher, Jochen Wirtz, \& Jacky Mussry, 2011. Pemasaran Jasa. Edisi 7. Jakarta: Erlangga.

Moorman, C., Deshpande', R. and Zaltman, G, 1992. Relationship Between Providers and Users of Market Research: The Role of Personal Trust, Marketing Science Institute, Cambridge, MA.

Morgan, R.M. and Hunt, S.D, 1994. The Commitment-Trust Theory of Relationship Marketing. Journal of Marketing, Vol. 58, No. 3, pp. 20-38.

Oliver, Riscrd L, 1997. Satisfaction A Behavioral Perspective On The Consumer. McGraw-Hill Education, Singapore. 
Randi S. M.

Prawira, A, 2010. Metodelogi Penelitian Jilid 1. Yogyakarta: PT. Grasindo.

Rousseau, D.M., Sitkin, B., Burt, R.S., Camerer, C, 1998. Not So Diffrent After All: a Cross-Dicipline View of Trust". Acad. Manage.Review, Vl.23, 393, 404.

Siti, Dwi dan Aryani, Lina, 2015. Pengaruh Kualitas Layanan dan Kepuasan Pelanggan Terhadap Loyalitas Pelanggan (Studi Kasus Pada Restoran Fast Food Pizza Hut di Jakarta Selatan). Artikel Fakultas Ekonomi Universtas Indonesia, Jakarta.

Sugiyono,2010. Metode penelitian Kuantitatif Kualitatif R\&D. Bandung: CV. Alfabeta.

Tjiptono, Fandy, 2008. Strategi Pemasaran. Yogyakarta: CV. Andi Offset.

Zeithaml, Valarie A. and Bitner, Mary Jo. 2003, Service Marketing. McGraw Hill Inc, Int'l Edition, New York, p.162 